\title{
Molecular Identification of Strains of Caridean Species in a Tropical Lagoons of South-Western Nigeria
}

\author{
M. F. Akinwunmi* , A. O. Lawal-Are \\ Department of Marine Sciences, Faculty of Science, University of Lagos, Nigeria
}

Received 3 July 2018, accepted in final revised form 29 September 2018

\begin{abstract}
Species identification by morphological approach requires a high degree of experience, which is difficult and not practical enough for those interested in surveying a broad diversity of organisms. However, molecular or genetic approaches to identify species have been proposed and widely used by most scientists. DNA barcoding was used to identify Macrobrachium species occurring in three coastal lagoons (Badagry, Lagos and Epe) in South-western Nigeria. Samples of prawns for the DNA studies were collected from May to July 2015. The DNA of the Macrobrachium species was extracted using the phenolchloroform protocol and Norgen tissue kit. Amplification and sequencing of the Macrobrachium species were carried out and further identification was done by comparing with sequenced data in the Genbank. New species of Macrobrachium were obtained in Badagry and Epe Lagoons having a close match with $M$. asperulum and $M$. nipponense at $85 \%$ and $84 \%$ respectively. M. asperulum and $M$. nipponense are reported in Badagry and Epe Lagoons for the first time.
\end{abstract}

Keywords: Macrobrachium spp.; Genomic DNA; South-western Nigeria lagoons.

(C) 2019 JSR Publications. ISSN: 2070-0237 (Print); 2070-0245 (Online). All rights reserved. doi: http://dx.doi.org/10.3329/jsr.v11i1.37282

J. Sci. Res. 11 (1), 111-120 (2019)

\section{Introduction}

The prawns, Macrobrachium species belonging to the family Palaemonidae are decapod crustaceans of high economic importance world-wide and have been subjected to intense aquacultural practices especially in Asia and the Americas [1,2]. Macrobrachium species occur in most inland waters including ponds, lakes, rivers and irrigation ditches, as well as in estuarine environment [3]. These prawns are found throughout the West African region. A total of about 200 species form the genus, in which only four species have been reported in Nigeria [4,5]. These include Macrobrachium vollenhovenii (African River

\footnotetext{
* Corresponding author: mfakinwunmi@gmail.com
} 
prawn), Macrobrachium macrobrachion (Brackish water prawn), Macrobrachium felicinum (Niger River prawn) and Macrobrachium dux (Congo River prawn).

There are morphological similarities between Macrobrachium olfersii which is found in Central America and other species such as M. faustinum (Saussure, 1857), M. crenulatum [6], M. digueti (Bouvier, 1895), M. hancocki [6] and $M$. acanthochirus (Villalobos, 1967). Recently, Macrobrachium birai and Macrobrachium holthuis were considered junior synonyms of $M$. olfersii $[7,8]$. This however, depicts that sometimes morphological analysis alone is not sufficient to resolve the diversity of species complexes. The use of molecular data is an advancement and has proven very useful to elucidate the taxonomic relationships in morphologically variable groups of freshwater prawns [9-13]. It has been proposed [14,15] the use of cytochrome c oxidase subunit I (COI) as a standard method to help identify species, define species boundaries and aid in species delimitation. As part of the DNA Barcoding framework, the COI gene based identification system has proved superior within taxonomic groups of Crustacea [16]. R. Udayasuriyan et al. [17] used the mt-COI gene for the DNA barcoding of freshwater prawn species as the phylogenetic information obtained through the gene sequences are more conserved and less subjected to evolutionary forces, and thus, their species are genetically distinct.

The DNA barcoding is emerging as an essential supportive tool for morphologybased species identification [18] and the technique involves building a reference database (Barcode of Life Database, BOLD) where data about the specimens (photographic, geographic, and taxonomic including locations of the voucher specimens) are combined with molecular data [19]. Subsequently, sequenced DNA barcodes from unknown specimens can be compared against this reference library for proper identification. The method also helps with the discovery of new species and characterization of the taxonomic and genetic diversity of different geographic regions and help resolve cryptic species complexes [20-23]. Although a unified barcode region has not been reached on a single barcoding DNA segment chosen for taxological studies [24].

Macrobrachium species which appears in Southern Nigeria are adapted to freshwater conditions by using molecular (mtDNA) technique [25]. Very little documented works are available on these prawns in Western lagoons in Nigeria.

This study was carried out to identify the prawn species collected from three coastal lagoons at South-West Nigeria by molecular identification.

\section{Materials and Methods}

\subsection{Study area}

The Badagry Lagoon, with source in River Queme in the Republic of Benin to the west of Nigeria, is located in Lagos State (Southwest Nigeria) and opens into the Atlantic Ocean via the Lagos harbour. It lies between longitudes $3^{\circ} 54^{\prime \prime}$ and $4^{\circ} 13^{\prime \prime} \mathrm{E}$ and latitudes $6^{\circ} 25^{\prime \prime}$ and $6^{\circ} 35^{\prime \prime} \mathrm{N}$ [26]. Lagos Lagoon is located between latitudes $6^{\circ} 26^{\prime}$ and $6^{\circ} 39^{\prime} \mathrm{N}$ and 
longitudes $3^{\circ} 29^{\prime}$ and $3^{\circ} 50^{\prime} \mathrm{E}$ [27] while Epe Lagoon lies between latitudes $6^{\circ} 29^{\prime \prime} \mathrm{N}$ and $6^{\circ} 38^{\prime \prime} \mathrm{N}$; and longitudes $3^{\circ} 30^{\prime \prime} \mathrm{E}$ and $4^{\circ} 05^{\prime \prime} \mathrm{E}$ [28].

\subsection{Source of prawn species}

Fifty-seven (57) prawn species used for the DNA extraction was collected from May to July 2015 from Badagry, Lagos and Epe Lagoons (Fig. 1). The specimens from the settraps in the lagoons were stored at $-20^{\circ} \mathrm{C}$ prior to use.

\subsection{Morphometrics measurement}

The meristic characters observed were the rostrum teeth (dorsal and ventral) while the morphometric characters: total length, standard length, telson length, carapace length, carapace weight, rostrum length, flesh weight, left cheliped length and right cheliped length were investigated. The meristic character was determined by counting the number of spines on the dorsal and ventral side of the rostrum. The total length involves measuring the prawns from the tip of the rostrum to the end of the telson (to the nearest $0.1 \mathrm{~cm}$ ) while the total weight was measured on an electronic weighing balance (Model: DT 1001A) to the nearest $0.01 \mathrm{~g}$. The carapace length was determined by measuring the prawn from the eye socket to posterior end of the carapace. The length of the telson, rostrum, left cheliped and right cheliped were also measured. The sexes were determined according to the method adopted by [29].

\subsection{DNA extraction}

The DNA extraction was carried using the slightly modified phenol-chloroform method [30,31], Norgen cells and tissue genomic DNA isolation kit from Norgen Biotek Corporation in Canada (Cat. Number: 53100). Samples of prawn species were given an acronym for easy labelling and identification as shown below:

Emv - M. vollenhovenii from Epe Lagoon, Emm - M. macrobrachion from Epe Lagoon, $\mathrm{Bmv}-$ M. vollenhovenii from Badagry Lagoon, Bmm - M. macrobrachion from Badagry Lagoon,

Lmv - M. vollenhovenii from Lagos Lagoon and Lmm - M. macrobrachion from Lagos Lagoon.

\subsection{Gel electrophoresis}

The quality of the DNA samples was checked on $2 \%$ agarose gel. The gel was run on 0.5 $\mathrm{X}$ Tris Borate EDTA (TBE) buffer at $75 \mathrm{~V}$ for $1.5 \mathrm{~h}$, then visualized by staining with 10 $\mathrm{mg} \mathrm{mL}^{-1}$ ethidium bromide under Ultra Violet (UV) light and photographed with the gel documentation system (UVitec, UK). 


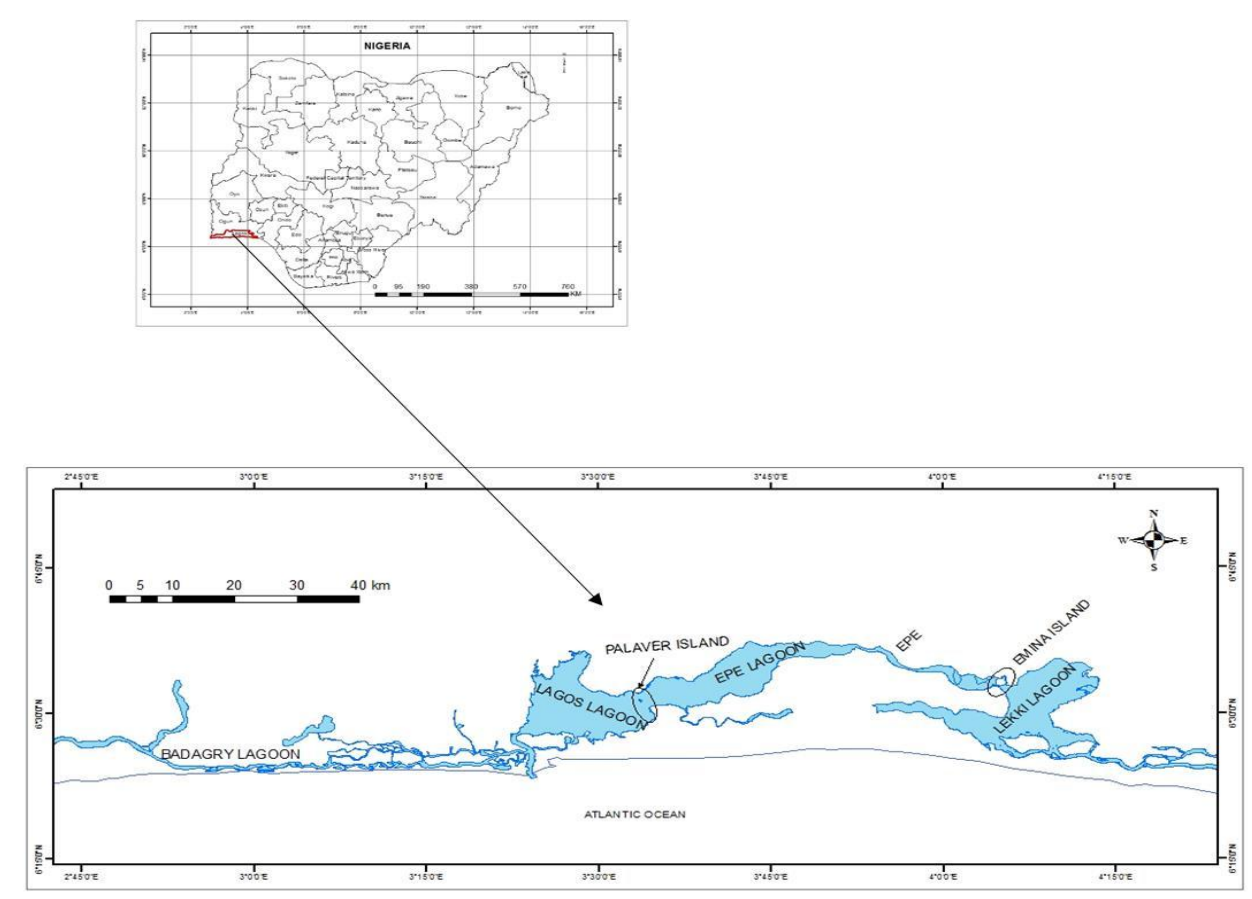

Fig. 1. Map of Badagry, Lagos and Epe Lagoons showing the sampling regions.

\subsection{Quantification of DNA samples}

The concentration of the DNA samples was determined using a spectrophotometer at 260 and $280 \mathrm{~nm}$, respectively. The DNA concentration ranges between 22 and $544 \mathrm{ng} / \mu \mathrm{L}$ was suitable for PCR amplification (1.09 and 3.56).

\subsection{DNA amplification and sequencing}

The extracted DNA samples were taken to Macrogen Europe Laboratory Meibergdreef 31 1105 AZ Amsterdam, Netherlands for the DNA amplification and sequence analysis. Amplification of the DNA fragment was determined by the Polymerase Chain Reaction (PCR) using Cytochrome Oxidase sub-unit 1 (CO1). The 5' end of cytochrome c oxidase sub unit I gene region was amplified using the primer pair LCO1490 (forward reaction): 5'-GGTCAACAAATCATAAAGATATTGG-3' and HCO2198 (reverse reaction): 5'TAAACTTCAGGGTGACCAAAAAATCA-3' [32]. The PCR conditions were programmed at $94{ }^{\circ} \mathrm{C}$ for five min (Pre-denaturation) followed by 35 cycles at $94{ }^{\circ} \mathrm{C}$ for one min (Denaturation), at $55{ }^{\circ} \mathrm{C}$ for one min (Annealing) and at $72{ }^{\circ} \mathrm{C}$ for one min (Extension). It was finally terminated at $72{ }^{\circ} \mathrm{C}$ for ten min and stored at $4{ }^{\circ} \mathrm{C}$ [33]. The PCR products were gel checked and sequenced based on the standard protocols [34]. PCR products were sequenced using a standard cycle-sequencing protocol of the ABI Big-Dye 
Ready Reaction Kit and analyzed on an Applied Biosystems automatic DNA sequencer (Model: 377, Applied Biosystems, CA, USA). The sequence data generated from the DNA extraction, PCR and sequences were further blasted in order to confirm their identities. Basic Local Alignment Search Tool (BLAST) was the program used to infer functional and evolutionary relationships between sequences as well as to help identify members of gene families. This was achieved by comparing nucleotide sequences data that were produced from the genomic DNA to sequences database at the Genbank.

\subsection{Statistical analysis}

Clean and clear unambiguous bands were scored for presence (1) and absence (0) of bands. The results for the quantification of the DNA samples were further analyzed using Microsoft excel (2007). The DNA sequences were automatically aligned using ClustalW [35] alignment algorithm under default parameters on Molecular Evolutionary Genetic Analysis (MEGA) 6.06 software [36]. Phylogenetic trees were derived using neighborjoining algorithms [37]. The robustness of the topologies for the neighbor-joining trees was estimated through bootstrap analysis [38] based on 1000 re-sampling of the sequences.

\section{Results}

Two new species were identified from the collected prawn samples (Plate 1). These were amplified using PCR and further sequenced. The reverse primer of Emm generated a length of 712 base pair (bp) on the chromatograph and while the sequences generated were blasted on the Genbank, it had a close match with Macrobrachium nipponense (of length $644 \mathrm{bp}$ ) at $84 \%$ close identity. The forward primer of Emm reproducibly generated amplification products of length 697 base pair (bp) at $83 \%$ close match with Macrobrachium nipponense (of length 640 as illustrated in Table 1).

The reverse primer of Bmv generated a length of 768 base pair (bp) on the chromatograph, it had a close match with Macrobrachium asperulum (of length $658 \mathrm{bp}$ ) at $85 \%$ close identity. The forward primer of Bmv reproducibly generated amplification products of length 715 base pair (bp) at $85 \%$ close match with Macrobrachium asperulum (of length $658 \mathrm{bp}$ ) as shown in Table 1. There is no observation of unique haplotypes from the result and there are variations in each member of sequences generated.

The phylogenetic analysis of the sequenced data yielded a neighbor-joining (NJ) tree as shown in Fig. 2. The meristic and morphometric characters of the identified species are presented in Table 2 with some of the characters from Badagry Lagoon showing slight differences from those of Epe Lagoon. The sequences generated were deposited in the National Centre for Biotechnology Information (NCBI) database on the $10^{\text {th }}$ of August, 2015 and these have been assigned Genbank accession numbers KT374065 - KT374068. 

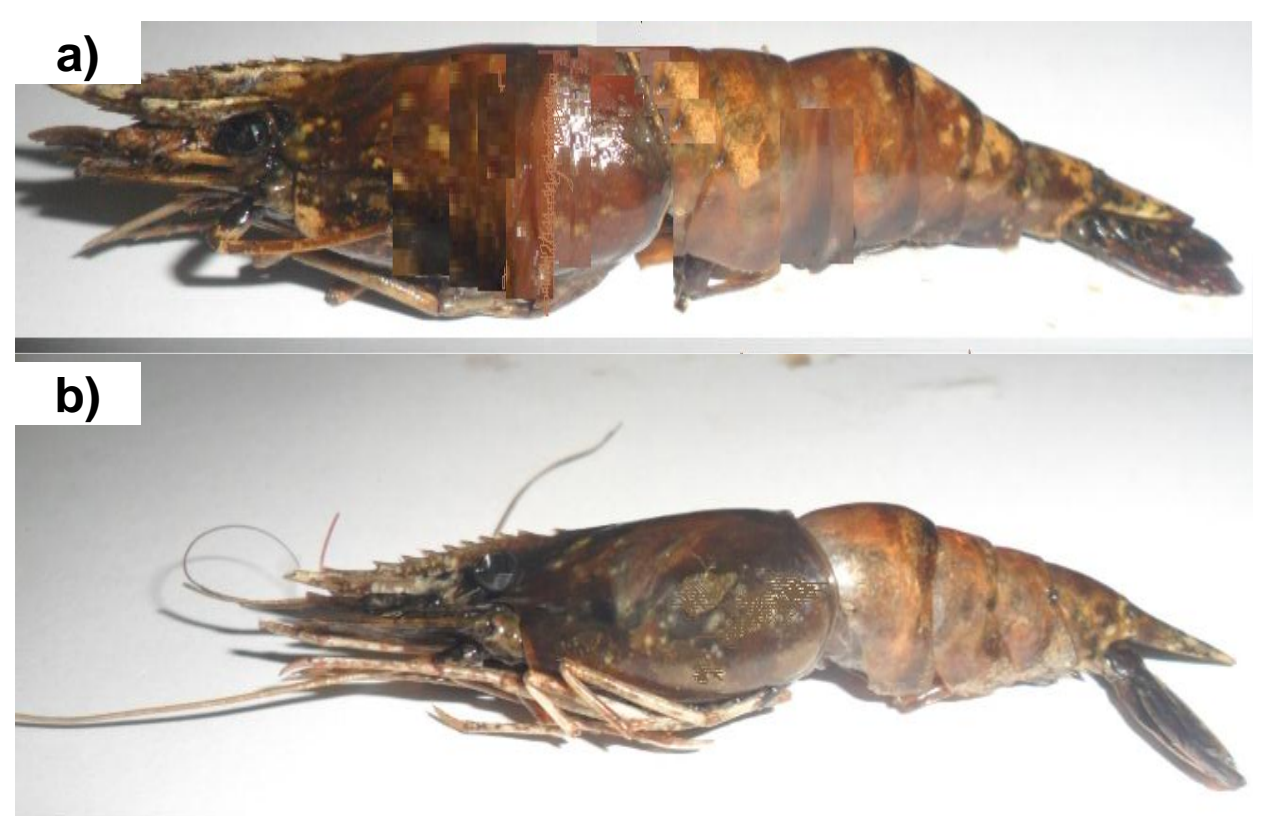

Plate 1. Identified prawns from the DNA barcode.
(a) Macrobrachium asperulum
(Mag. x 0.8)
(b) Macrobrachium nipponense
(Mag. x 0.7)

Table 1. Percentage closeness of the identified species in relation to GenBank sequence.

\begin{tabular}{|c|c|c|c|c|c|c|}
\hline Query & & & & & & Identities \\
\hline Name & $\begin{array}{l}\text { Length (base } \\
\text { pair-bp) }\end{array}$ & S equences & Gene & $\begin{array}{l}\text { Length (base } \\
\text { pair-bp) }\end{array}$ & Match & Pct. (\%) \\
\hline $\begin{array}{l}\text { 150305- } \\
\text { 32_E01/ME4/Emm } \\
\text { HCO2198 } \\
\text { (KT 374065) }\end{array}$ & 712 & $\begin{array}{l}\text { GCGG AAG ATGCTGCGCA } \\
\text { TAGCG ATTGTG GTCTCC } \\
\text { CCCACCTGCCG GGTCAA } \\
\text { AG AAAGAG GTGTTT }\end{array}$ & $\begin{array}{l}\text { Macrobrachium nipponense } \\
\text { mitochondrial COl gene for } \\
\text { cytochrome c oxidase } \\
\text { subunit } 1 \text {, partial cds, isolate: } \\
\text { MNl }\end{array}$ & 644 & 533 & 84 \\
\hline $\begin{array}{l}\text { 150305- } \\
\text { 32_G01_ME4/EmmL } \\
\text { CO1490(KT 374066) }\end{array}$ & 697 & $\begin{array}{l}\text { CGAGGAA TGTTG TCTTC } \\
\text { GG AGCGTG AGCTGGGAT } \\
\text { AG TAGG CACA TCTCTGA } \\
\text { GACTCCTTATCCGGGC }\end{array}$ & $\begin{array}{l}\text { Macrobrachium nipponense } \\
\text { mitochondrion, complete } \\
\text { genome }\end{array}$ & 640 & 556 & 83 \\
\hline $\begin{array}{l}150305- \\
32 \_ \text {I01_MB5/Bmv } \\
\text { HCO 2198 } \\
\text { (KT 374067) }\end{array}$ & 768 & $\begin{array}{l}\text { GG GAAAGTG TTGGAGG } \\
\text { AG AATG GGG TCTCCCCC } \\
\text { TCCTGCGGGG TCG AAG A } \\
\text { AAGAG TATTTAGG }\end{array}$ & $\begin{array}{l}\text { Macrobrachium asperulum } \\
\text { mitochondrial COI gene for } \\
\text { cytochrome oxidase subunit } \\
\text { I, partial cds, haplotype: TH- } \\
3\end{array}$ & 658 & 562 & 85 \\
\hline $\begin{array}{l}\text { 150305- } \\
\text { 32_K01_MB5/Bmv } \\
\text { LCO1490 } \\
\text { (KT 374068) }\end{array}$ & 715 & $\begin{array}{l}\text { CCAATATTTTTTATCTGT } \\
\text { CGTGAGCTTGAG CAGGA } \\
\text { ATAGTAGGCACATCCTC } \\
\text { TAAGACTTCTTAAT }\end{array}$ & $\begin{array}{l}\text { Macrobrachium asperulum } \\
\text { mitochondrial COI gene for } \\
\text { cytochrome oxidase subunit } \\
\text { I, partial cds, haplotype: TH- } \\
3\end{array}$ & 658 & 562 & 85 \\
\hline
\end{tabular}




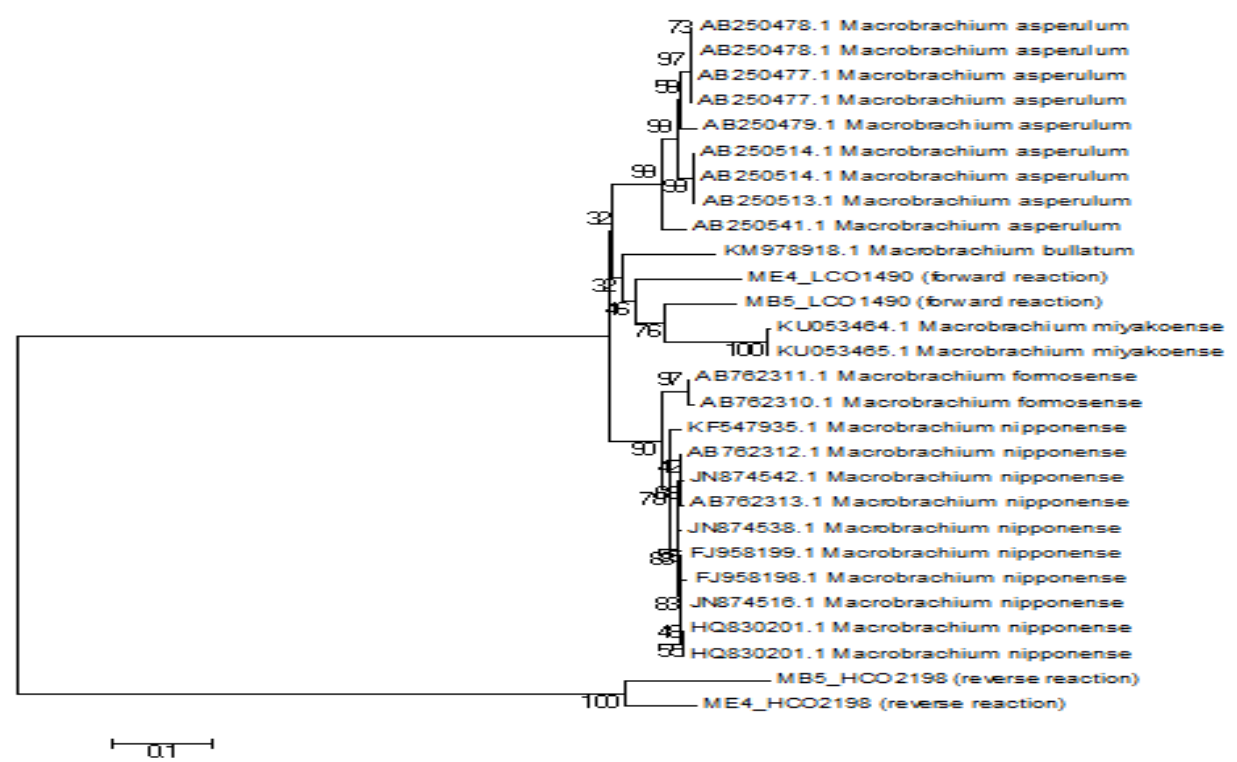

Fig. 2. Neighbor-joining (NJ) tree based on the COI sequenced data.

Table 2. Meristic and morphometric (morphomerics) characters of the identified species from the study area.

\begin{tabular}{|c|c|c|c|c|c|c|c|c|c|c|c|c|c|}
\hline Species & $\begin{array}{c}\mathrm{TL} \\
(\mathrm{cm})\end{array}$ & $\begin{array}{c}\mathrm{SL} \\
(\mathrm{cm})\end{array}$ & $\begin{array}{l}\text { TW } \\
(\mathrm{g})\end{array}$ & $\begin{array}{c}\text { Tel- } \\
\mathrm{L}(\mathrm{cm}) \\
\end{array}$ & $\begin{array}{c}\mathrm{CL} \\
(\mathrm{cm})\end{array}$ & $\begin{array}{c}\text { CW } \\
(\mathrm{g})\end{array}$ & $\begin{array}{l}\mathrm{RL} \\
(\mathrm{cm}) \\
\end{array}$ & $\begin{array}{c}\mathrm{RT} \\
\text { dorsal } \\
\end{array}$ & $\begin{array}{c}\mathrm{RT} \\
\text { ventral }\end{array}$ & SEX & $\begin{array}{r}\text { FW } \\
(\mathrm{g})\end{array}$ & LCL & RCL \\
\hline \multicolumn{14}{|c|}{ Badagry Lagoon } \\
\hline MB5 & 10.1 & 8.7 & 16.0 & 1.4 & 3.0 & 0.6 & 3.0 & 15 & 4 & M & 7.2 & 8.8 & 5.4 \\
\hline \multicolumn{14}{|c|}{ Epe Lagoon } \\
\hline ME4 & 7.5 & 6.5 & 5.5 & 1.0 & 2.2 & 0.3 & 2.1 & 13 & 4 & M & 3.2 & 10.4 & 12.5 \\
\hline
\end{tabular}

Key:

TL $=$ Total Length

Tel-L = Telson Length

$\mathrm{RL}=$ Rostral Length

LCL $=$ Left Cheliped Length

\author{
$\mathrm{SL}=$ Standard Length \\ $\mathrm{CL}=$ Carapace Length \\ RT $=$ Rostrum Teeth \\ RCL $=$ Right Cheliped Length
}

\author{
TW $=$ Total Weight \\ $\mathrm{CW}=$ Carapace Weight \\ $\mathrm{FW}=$ Flesh Weight
}

\section{Discussion}

The studies revealed that only two prawn samples were isolated for DNA sequenced while the remaining species could not be included in barcode analysis due to the fact that they were not successfully amplified with the universal primer (LCO1490 and HCO2198) used in this study. This may be due to several reasons right from the preservation of samples, handling of tissue samples to the steps involved in the DNA extraction and PCR amplification [23]. 
The result obtained from the morphometric characterization showed that both species had more rostrum teeth on the dorsal part than the ventral side. Though, MB5 from Badagry Lagoon had more teeth on the dorsal part of the rostrum than that of ME4 from Epe Lagoon while both species had the same number of spines on the ventral side of the rostrum. A significant differences was recorded in some of the morphometric characters (TL, TW, FW and RCL) from Badagry and Epe Lagoon, the observed variation from the two lagoons probably reflected environmental differences, Badagry and Epe Lagoons being low brackish waterbodies. Therefore, this environmental differences might be a factor responsible for the varied meristic and morphometric characters. On the contrary [39] mention that the species recorded 5 spines as the highest frequency of occurrence on the ventral side of M. macrobrachion and $M$. vollenhovenii respectively and on the dorsal side, 9 spines occurred in the most for $M$. macrobrachion while 9 and 10 spines occurred in most for M. vollenhovenii. However, S. D. Salman et al. [40] recorded a range of 11-14 and 1-3 spines on the dorsal and ventral rostrum teeth of $M$. nipponense respectively and the total length of the males ranged between $71.00-99.80 \mathrm{~mm}(7.10-9.98 \mathrm{~cm}) . \mathrm{G}$. Ahmad [41] also observed 11 and 2 spines on the dorsal and ventral side of the rostrum teeth of $M$. nipponense respectively and a maximum total length of the male species as $75.4 \mathrm{~mm}(7.54 \mathrm{~cm})$. According to the references [42,43], rostrum, teeth, morphology of the walking legs, palm and fingers have been viewed as useful and diagnostic taxonomic characters in prawns.

The DNA sequence data showed that M. nipponense and M. asperulum had $84 \%$ and $85 \%$ similarity with strains of $M$. macrobrachion and $M$. vollenhovenii from Epe and Badagry Lagoons respectively. Thus, it can be concluded that $M$. asperulum and $M$. nipponense can be found in Badagry and Epe Lagoons respectively (though they were of narrow gene pool) due to the relatively close match with sequences from the Genbank. The occurrence of $M$. asperulum and M. nipponense in the lagoons might be as a result of the low salinity of Badagry and Epe Lagoons during the rainy season. S. Shokita [44] reported that $M$. asperulum completes its life cycle only in freshwater. M. H. Ali [45] reported the occurrence of $M$. nipponense in Iraq, in waters with salinity range of $1.299-$ $2.690 \%$. Q. A. Nguyen et al. [46] reported the occurrence of M. nipponense in Iran while A. Dimmock [47] found that environmental other than genetic factor could determine differences in morphological characters when identifying Macrobrachium species.

The use of molecular technique was employed to identify new species of Macrobrachium that were found during the period of collections. The PCR amplification and the universal decapods primer (LCO1490 and HCO2198) used in this study brought to light the emergence of new strains of Macrobrachium species from Epe and Badagry Lagoons, Nigeria. It is therefore important to employ the use of more molecular methods to investigate the possibilities of exploitations of these species in South-West Lagoons especially in Epe, Badagry Lagoons and adjacent waterbodies as it seems that the species are getting adapted to the new environment, though they constitute small gene pool. 


\section{Conclusion}

In this study, new Macrobrachium species (M. asperulum and M. nipponense) were found in Badagry and Epe Lagoons using two protocols for the DNA extraction. It is therefore very important to adopt the use of more molecular methods to investigate the possibilities of exploitations of these species and also put into considerations several reasons right from the preservation of samples, handling of tissue samples to the steps involved in the DNA extraction and PCR, as these may interfere with the quality and quantity of the DNA samples.

\section{Acknowledgments}

The authors are grateful to the Graduate Fellow scheme of the School of Postgraduate studies (SPGS) UNILAG for the financial assistance. This work was supported by T. Ogundipe and T. Onuminya, Dept. of Botany, for the facilities provided during the DNA extraction process. The authors are most grateful to Emeritus Prof. K. Kusemiju of the Dept. of Marine Sci. and A. Ogunkanmi of the Dept. of Cell Biology and Genetics who checked the manuscript.

\section{References}

1. FAO, Food and Agriculture Organisation of the United Nations (Bangkok, Thailand, 2006), pp. 20.

2. L. A. Davassi, J. Fisher. Aquat. Sci. 6, 649 (2011).

3. M. B. New, Food and Agriculture Organization Fisheries Technical Paper 428, (2002).

4. I. E. Marioghae, Revue Zoologique Africaine. 96, 3 (1982).

5. O. A. Bello-Olusoji, A. T. Omolayo, and A. Arinola, J. Food Agric. Environ. 2, 280 (2004).

6. L. B. Holthuis, Siboga Expedition Monograph 39, 1 (1950).

7. L. G. Pileggi and F. L. Mantelatto, Invertebrate Systematics 24, 1 (2010). https://doi.org/10.1071/IS10009

8. L. G. Pileggi and F. L. Mantelatto, Iheringia Série Zoologia 102, 4 (2012).

9. N. P. Murphy and C. M. Austin, Aust. J. Zool. 52, 5 (2004). https://doi.org/10.1071/ZO03062

10. D. H. N. Munansinghe, J. National Sci. Found. Sri Lanka 38, 3 (2010). https://doi.org/10.4038/jnsfsr.v38i1.1721

11. F. G. Vergamini, L. G. Pileggi, and F. L. Mantelatto, Contribut. Zool. 80, 1 (2011).

12. K. V. Rintelen, T. J. Page, Y. Cai, K. Roe, B. Stelbrink, B. R. Kuhajda, T. M. Iliffe, J. Hughes, and T. Von-Rintelen, Mol. Phylogen. Evolut. 63, 1 (2012). https://doi.org/10.1016/j.ympev.2011.11.018

13. L. S. Torati and F. L. Mantelatto, J. Crust. Biol. 32, 4 (2012). https://doi.org/10.1163/193724012X635322

14. P. D. N. Hebert, A. Cywinska, S. L. Ball, and J. R. De-Waard - Proceed. of the Royal Soc. of London, Series B: Biolog. Sci. 270, 1512 (2003).

15. Y. M. Saad and H. E. A. El-Sadek, Int. School. Sci. Res. Innov. 11, 515 (2017).

16. T. Lefébure, C. J. Douady, M. Gouy, and J. Gibert, Mol. Phylogen. Evolut. 40, 2 (2006). https://doi.org/10.1016/j.ympev.2006.03.014

17. R. Udayasuriyan, B.P. Saravana, and R. Kalpana, J. Gene Proteins 1, 1 (2017).

18. K. Shantanu, R. Shibananda, T. Kaomud, C. Rajasree, and K. Vikas, Mitochondrial DNA 3, 1 (2018). https://doi.org/10.1080/23802359.2017.1413288 
19. P. D. N. Hebert, J. R. De-Waard, E. V. Zakharov, S. W. Prosser, J. E. Sones, J. T. McKeown, B. Mantle, and J. La-Salle, PLoS One 8, 7 (2013). https://doi.org/10.1371/journal.pone.0068535

20. P. D. Hebert and R. T. Gregory, Systematic Biology 54, 852 (2005). https://doi.org/10.1080/10635150500354886

21. F. O. Costa, J. R. De-Waard, J. Boutillier, S. Ratnasingham, R. T. Dooh, M. Hajibabaei, and P. D. Hebert, Can. J. Fish. Aquat. Sci. 64, 272 (2007). https://doi.org/10.1139/f07-008

22. M. Hajibabaei, G. A. Singer, P. D. Hebert, and D. A. Hickey, Trends in Genetics 23, 167 (2007).

23. G. Rajkumar, P. S. Bhavan, R. Udayasuriyan, and C. Vadivalagan, Int. J. Fish. Aquat. Stud. 2, 4 (2015).

24. S. Lin, H. Zhang, Y. B. Hou, Y. Y. Zhuang, and L. Miranda, Appl. Environ. Microbiol. 75, 5 (2009). https://doi.org/10.1128/AEM.00824-09

25. A. A. Jimoh, M. A. Anetekhai, S. Cummings, O. T. Abanikanda, G. F. Turner, C. V. Oosterhout, and B. Hanfling, Aquaculture 410, 25 (2013). https://doi.org/10.1016/j.aquaculture.2013.06.013

26. A. O. Lawal-Are and K. Kusemiju, J. Sci. Res. Develop. 4, 117 (2000).

27. P. E. Ndimele, M.Sc. Dissertation, University of Ibadan, Nigeria, 2003.

28. J. I. Agboola and M. A. Anetekhai, J. Appl. Ichthyol. 24, 623 (2008). https://doi.org/10.1111/j.1439-0426.2008.01079.x

29. M. A. Anetekhai, Ph.D. Thesis, University of Ibadan, 1986.

30. J. Sambrook, E. F. Fritsch, and T. Maniatis, Molecular Cloning: A Laboratory Manual., $2^{\text {nd }}$ Edition (Cold Spring Harbor Laboratory Press, 1989) 11, pp. 2.

31. J. Sambrook and D. W. Russell, Molecular Cloning 1-3, 2100 (2001).

32. O. Folmer, M. Black, W. Hoeh, R. Lutz, and R. Vrijenhoek, Mol. Marine Biol. Biotech. 3, 294 (1994).

33. S. Nicole, E. Negrisolo, G. Eccher, R. Mantovani, T. Patarnello, D. L. Erickson, W. J. Kress, and G. Barcaccia, Food Tech. Biotech. 50, 4 (2012).

34. K. S. Ajmal, P. S. Lyla, J. B. Akbar, K. C. Prasanna, S. Murugan, and K. C. Jalal, Biotech. 9, 3 (2010).

35. J. D. Thompson, D. G. Higgins, and T. J. Gibson, Nucl. Acids Res. 22, 22 (1994). https://doi.org/10.1093/nar/gni186

36. K. Tamura, G. Stecher, D. Peterson, A. Filipski, and S. Kumar, Mol. Biol. Evolut. 30, 12 (2013). https://doi.org/10.1093/molbev/mst197

37. K. Strimmer and A. Von-Haeseler, Mol. Biol. Evolut. 13, 7 (1996). https://doi.org/10.1093/oxfordjournals.molbev.a025664

38. J. Felsenstein, Evolution 39, 4 (1985). https://doi.org/10.1111/j.1558-5646.1985.tb00420.x

39. A. A. Jimoh, E. O. Clarke, O. O. Whenu, M. A. Anetekhai, and P. E. Ndimele, Asian J. Biol. Sci. 5, 126 (2012).

40. S. D. Salman, J. P. Timothy, D. N. Murtada, and G.Y. Ama'al, Aquatic Invasions. 1, 3 (2006). https://doi.org/10.3391/ai.2006.1.3.2

41. G. Ahmad, Adv. J. Biol. Sci. Res. 1, 003 (2013).

42. P. Naiyanetr, Crustaceana 74, 609 (2001). https://doi.org/10.1163/156854001505541

43. N. P. Murphy and C. M. Austin, Zoologica Scripta. 34, 187 (2005). https://doi.org/10.1111/j.1463-6409.2005.00185.x

44. S. Shokita, Annotations Zoologicae Japonenses. 50, 110 (1977).

45. M. H. Ali, S. D. Salman, and A.Y. Al-Adhub, Scientia Marina. 59, 1 (1995).

46. Q. A. Nguyen, D. P. Phan, T. L. Phan, T. T. Nguyen, and B. Le-Phoc-Proc. of the $6^{\text {th }}$ Technical Symp. on Mekong Fisheries (Pakse, Lao PDR., 2003) 26.

47. A. Dimmock, L. Williamson, and P. B. Mather, Aquacult. Int. 12, 435 (2004). https://doi.org/10.1023/B:AQUI.0000042140.48340.c8 